\title{
GENE ACTIONS FOR HECTOLITER MASS IN SUNFLOWER (Helianthus annuus L.)
}

\author{
Marinković, R. ${ }^{*}$, Jovanović, D. and Joksimović, J. \\ Institute of Field and Vegetable Crops, Maksima Gorkog 30, \\ 21000 Novi Sad, Serbia \\ Received: September 10, 2005 \\ Accepted: March 25, 2006
}

\section{SUMMARY}

Effects of additive and dominant genes and their interactions on the inheritance of hectoliter weight in 10 sunflower hybrids developed by crossing five inbred lines derived from the synthetic NS-S-1 were analyzed in 2001 and 2002. The linkage among the expected progeny means was tested using the scaling tests method (Mather, 1949), while the estimates of gene effects and mode of inheritance were made by generation mean analysis (Mather and Jinks, 1982). The additive-dominant model was not adequate for all crosses from the two years. In the hybrids for which the model was not adequate, epistatic gene effects were important in the inheritance of the studied characters.

In the first year of study, duplicate epistasis between dominant increasers was expressed in crosses $\mathrm{C}_{2}$ and $\mathrm{C}_{9}$, while duplicate epistasis between dominant decreasers occurred in crosses $\mathrm{C}_{5}$ and $\mathrm{C}_{6}$. In the second year of study duplicate epistasis between dominant increasers was expressed only in the cross $\mathrm{C}_{5}$, while duplicate epistasis between dominant decreasers occurred in crosses $\mathrm{C}_{1}, \mathrm{C}_{4}, \mathrm{C}_{6}, \mathrm{C}_{7}$ and $\mathrm{C}_{10}$. In the crosses $\mathrm{C}_{1}, \mathrm{C}_{3}, \mathrm{C}_{4}, \mathrm{C}_{7}, \mathrm{C}_{8}$ and $\mathrm{C}_{10}$ in the first year and in the crosses $\mathrm{C}_{2}, \mathrm{C}_{3}, \mathrm{C}_{8}$ and $\mathrm{C}_{9}$ in the second year of investigation the type of epistasis could not be determined, because the values of the non-fixable components (dominant and dominant $\times$ dominant) were insignificant.

Key words: additive, dominant, epistase, scaling test, generation mean analysis

\section{INTRODUCTION}

The oil-type sunflower hybrids that are currently in commercial production have a high oil content (up to 50\%) and a relatively low husk content (up to $22 \%$ ) but they do not have high values of hectoliter weight. Development of hybrids with high volumic weight would be advantageous for sunflower production. Soldatov and Mamaonov (1972) claimed that increased hectoliter weight would bring down the

* Corresponding author, Phone: +381 214898 410, Fax: +381 21413 833, e-mail: radomar@ifvens.ns.ac.yu 
need for transportation vehicles for sunflower seed transportation, permitting their use for other purposes.

Opinion of individual researchers that seeds with high hectoliter weight have high oil content and vice versa, has been refuted in numerous studies.

Hectoliter weight is a variable character which is influenced by both genetic and environmental factors. Studying combining ability in some sunflower inbred lines, Marinković (1984) found that the inbred lines varied in hectoliter weight from 29.3 to $48.8 \mathrm{~kg} / \mathrm{hl}$, while their combinations varied from 38.3 to $52.9 \mathrm{~kg} / \mathrm{hl}$. The analysis of the mode of inheritance of this character had indicated the predominance of nonadditive genes.

The objectives of this study were to gain information on the mode of inheritance and gene action for hectoliter weight in selected sunflower inbred lines as well as to check the adequacy of the additive-dominant model for the character under study.

\section{MATERIAL AND METHOD}

The inbred lines used in this study were developed from NS-S-1, a synthetic made at Institute of Field and Vegetable Crops in Novi Sad from eight lines applying the convergent cross method and following the principle of maximum recombination. The lines used for the development of the synthetic are the female lines in the best domestic hybrids, NS-H-26 RM, NS-H-27 RM, NS-H-45 and NS-H-43.

From several scores of inbred lines derived from the synthetic during 6 years of inbreeding, we selected five for intercrossing conducted in 1998. In the plants used as females, anthers were removed by hand. A total of 10 crosses were made: $c_{1}$ (nsmr-1 $\times$ ns-mr-2), $c_{2}\left(n s-m r-1 \times\right.$ ns-mr-3), $c_{3}\left(n s-m r-1 \times\right.$ ns-mr-4), $c_{4}(n s-m r-1 \times$ ns-mr-5), $c_{5}$ (ns-mr-2 $\times$ ns-mr-3), $c_{6}$ (ns-mr- $\times$ ns-mr-4), $c_{7}$ (ns-mr-2 $\times$ ns-mr-5), $\mathrm{c}_{8}$ (ns-mr-3 $\times$ ns-mr-4), $\mathrm{c}_{9}$ (ns-mr-3 $\times$ ns-mr-3) and $\mathrm{c}_{10}$ (ns-mr-4 $\times$ ns-mr-5). In the year 2000 , the $\mathrm{F}_{2}$ generation and backcrosses with both parents $\left(\mathrm{BC}_{1} \mathrm{P}_{1} ; \mathrm{BC}_{1} \mathrm{P}_{2}\right)$ were produced.

The experiment involving the parent lines, $\mathrm{F}_{1}$ hybrids, $\mathrm{F}_{2}$ generations and backcrosses was established at Rimski Šančevi experiment field in 2001 and 2002. The experiment in random blocks design was replicated three times. Experimental material was planted manually in a carefully prepared seedbed at an optimum period. The distances between and within the row were 70 and $30 \mathrm{~cm}$, respectively. Since several seeds were placed in each hill, thinning had to be performed at the stage of 2-3 pairs of permanent leaves. The parent lines and $\mathrm{F}_{1}$ hybrids were each planted in 4 rows, the $\mathrm{F}_{2}$ generation and backcrosses in 8 rows. In the course of growing season, rototilling and hoeing were used to eradicate the weed plants that survived herbicide application.

Hectoliter weight $(\mathrm{kg} / \mathrm{hl})$ of seed was determined in the laboratory after the threshing of individual heads. The sample size was 20 plants per replication for the 
parents and $F_{1}$ hybrids, or 60 plants per experiment, and 60 plants per replication for the $\mathrm{F}_{2}$ and backcross generations, or 180 plants per experiment. The border rows and the first and last plants in the row were excluded from sampling.

Individual scaling tests and estimates of additive, dominant and epistatic gene effects were done according to the models of Mather (1949) and Mather and Jinks (1982).

\section{RESULTS AND DISCUSSION}

The calculated mean values of the scaling tests (A, B and C) and their dispersion indicate that the null hypothesis on the sole effect of additive or dominant genes on the mean values in the progenies could be accepted for three crosses $\left(\mathrm{C}_{1}\right.$, $\mathrm{C}_{5}$ and $\left.\mathrm{C}_{8}\right)$ in the first and two crosses $\left(\mathrm{C}_{2}\right.$ and $\left.\mathrm{C}_{9}\right)$ in the second year of study (Table 1). The other crosses had at least one test that was either significant or highly significant. This was an indication that the inheritance of the latter crosses included also some other parameters, such as digenic epistatic gene effects.

Table 1: Scaling test of progeny and their dispersion for hectoliter mass in sunflower in two years

\begin{tabular}{|c|c|c|c|c|c|c|}
\hline \multirow{2}{*}{ Cross } & \multicolumn{3}{|c|}{ Scaling test 2001} & \multicolumn{3}{|c|}{ Scaling test 2002} \\
\hline & A & B & C & A & B & C \\
\hline $\mathrm{C}_{1}$ & $-1.39 \pm 2.10$ & $0.89 \pm 1.31$ & $3.83 \pm 2.34$ & $-3.24 \pm 0.85^{\star *}$ & $-6.96 \pm 1.52^{\star \star}$ & $-7.64 \pm 2.24^{\star \star}$ \\
\hline $\mathrm{C}_{2}$ & $-0.64 \pm 0.81$ & $3.71 \pm 1.14^{\star}$ & $-0.43 \pm 1.65$ & $-0.08 \pm 1.45$ & $0.44 \pm 0.61$ & $-1.62 \pm 3.26$ \\
\hline $\mathrm{C}_{3}$ & $-1.85 \pm 1.84$ & $4.24 \pm 1.20^{\star}$ & $3.88 \pm 1.20$ & $-5.98 \pm 0.61 * *$ & $0.64 \pm 0.50$ & $-7.42 \pm 1.55^{\star *}$ \\
\hline $\mathrm{C}_{4}$ & $0.24 \pm 1.29$ & $3.37 \pm 0.56^{\star \star}$ & $3.85 \pm 1.80$ & $-2.24 \pm 0.64^{\star}$ & $2.12 \pm 0.75^{\star}$ & $5.84 \pm 1.33^{\star *}$ \\
\hline $\mathrm{C}_{5}$ & $-2.65 \pm 1.09$ & $-3.28 \pm 2.38$ & $1.35 \pm 2.34$ & $2.98 \pm 0.82^{\star}$ & $3.60 \pm 0.85^{\star *}$ & $4.30 \pm 1.34^{*}$ \\
\hline $\mathrm{C}_{6}$ & $3.37 \pm 0.80^{* *}$ & $1.97 \pm 1.22$ & $13.36 \pm 1.91^{\text {** }}$ & $-4.10 \pm 0.93^{\star *}$ & $3.25 \pm 0.94^{*}$ & $8.70 \pm 1.79^{\star *}$ \\
\hline $\mathrm{C}_{7}$ & $4.29 \pm 1.06^{* *}$ & $1.85 \pm 1.48$ & $11.81 \pm 2.12^{\star *}$ & $-0.62 \pm 1.32$ & $-3.38 \pm 1.70$ & $6.72 \pm 1.18^{\star *}$ \\
\hline $\mathrm{C}_{8}$ & $2.65 \pm 1.28$ & $3.31 \pm 2.58$ & $5.83 \pm 2.65$ & 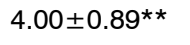 & $2.60 \pm 0.48^{\star *}$ & $9.60 \pm 1.27^{\star \star}$ \\
\hline $\mathrm{C}_{9}$ & $3.64 \pm 1.61$ & $3.05 \pm 1.15^{\star}$ & $4.44 \pm 3.27$ & $1.26 \pm 0.56$ & $1.28 \pm 0.57$ & $4.54 \pm 2.38$ \\
\hline $\mathrm{C}_{10}$ & $-0.48 \pm 1.04$ & $7.92 \pm 2.12^{\star \star}$ & $15.31 \pm 2.75^{\star *}$ & $1.00 \pm 0.74$ & $2.22 \pm 1.99$ & $11.62 \pm 1.65^{\star \star *}$ \\
\hline
\end{tabular}

Since it was shown that the model adequate for one cross may be inadequate for another cross having the same scope of variability, or it may be even less adequate for a cross having a larger scope of variability, we conducted a joint scaling test.

Eventually, using a model with six parameters, we found in some crosses that the studied character was controlled by additive and dominant gene effects, as well as by different epistatic gene effects in the two years of study (Table 2). Effects of additive and dominant genes and their interactions on the inheritance of hectoliter weight were not the same in the analyzed crosses.

In the first year of study, highly significant effects of additive genes were exhibited in crosses $\mathrm{C}_{1}, \mathrm{C}_{3}, \mathrm{C}_{4}, \mathrm{C}_{5}, \mathrm{C}_{6}, \mathrm{C}_{7}$ and $\mathrm{C}_{8}$, while a highly significant effect of dom- 
inant genes was exhibited only in the cross $C_{2}$. In crosses $C_{5}, C_{6}$ and $C_{9}$, significant effects of dominant genes occurred in addition to the highly significant effects of additive genes. In the cross $\mathrm{C}_{2}$, major contributors to epistasis were the interaction additive $\times$ dominant $(j)$ as well as the interactions additive $\times$ additive $(i)$ and dominant $\times$ dominant $(l)$. In the cross $\mathrm{C}_{5}$, major contributors to epistasis were the interactions additive $\times$ additive $(i)$ and dominant $\times$ dominant $(l)$, in the cross $\mathrm{C}_{6}$-the interactions additive $\times$ additive $(i)$ and dominant $\times$ dominant $(l)$, in the cross $\mathrm{C}_{6}$ the interaction additive $\times$ additive $(i)$, and in the cross $\mathrm{C}_{9}$ - the interaction dominant $\times$ dominant.

Table 2a: Gene effects for hectoliter mass in ten sunflower crosses in 2001

\begin{tabular}{|c|c|c|c|c|c|c|c|}
\hline \multirow{2}{*}{ Cross } & \multicolumn{6}{|c|}{ Gene effect } & \multirow{2}{*}{ Type of epistasis } \\
\hline & $\mathrm{m}$ & $\mathrm{d}$ & $\mathrm{h}$ & $\bar{i}$ & j & I & \\
\hline $\mathrm{C}_{1}$ & $46.19 * \star$ & $1.11^{\star \star}$ & -11.14 & -4.32 & -2.28 & 4.81 & \\
\hline $\mathrm{C}_{2}$ & $36.79 * *$ & 0.48 & $10.37 * *$ & $3.49 *$ & $-4.35^{\star \star}$ & $-6.56^{\star}$ & $\begin{array}{l}\text { Duplicate epistasis between } \\
\text { dominant increasers }\end{array}$ \\
\hline $\mathrm{C}_{3}$ & $39.47^{* *}$ & $2.78^{\star \star}$ & -0.82 & -1.49 & $-6.09 *$ & -0.89 & \\
\hline $\mathrm{C}_{4}$ & $38.89 * *$ & $2.11^{\star \star}$ & 5.35 & -0.24 & $-3.13^{*}$ & -3.37 & \\
\hline $\mathrm{C}_{5}$ & $48.67^{\star \star}$ & $1.59 * \star$ & $-17.29 *$ & $-7.28^{\star}$ & 0.63 & $13.21^{\star}$ & $\begin{array}{l}\text { Duplicate epistasis between } \\
\text { dominant decreasers }\end{array}$ \\
\hline $\mathrm{C}_{6}$ & $47.11^{* *}$ & $3.89 * \star$ & $-12.75^{\star}$ & -8.01 ** & 1.40 & 2.67 & $\begin{array}{l}\text { Duplicate epistasis between } \\
\text { dominant decreasers }\end{array}$ \\
\hline $\mathrm{C}_{7}$ & $45.43^{\star \star}$ & $3.23^{\star \star}$ & -6.35 & $-5.67^{\star *}$ & 2.44 & -0.48 & \\
\hline $\mathrm{C}_{8}$ & $37.37^{\star \star}$ & $2.30 * \star$ & 10.99 & 0.13 & -0.65 & -6.09 & \\
\hline $\mathrm{C}_{9}$ & 35.91 ** & $1.63^{* *}$ & $13.33^{\star}$ & 2.25 & 0.59 & $-8.95^{\star}$ & $\begin{array}{l}\text { Duplicate epistasis between } \\
\text { dominant increasers }\end{array}$ \\
\hline $\mathrm{C}_{10}$ & $43.73^{\star \star}$ & 0.67 & -6.56 & -7.87 & $-8.40 * \star$ & 0.43 & \\
\hline
\end{tabular}

Table 2b: Gene effects for hectoliter mass in ten sunflower crosses in 2002

\begin{tabular}{|c|c|c|c|c|c|c|c|}
\hline \multirow{2}{*}{ Cross } & \multicolumn{6}{|c|}{ Gene effect } & \multirow{2}{*}{ Type of epistasis } \\
\hline & $\mathrm{m}$ & d & $\mathrm{h}$ & $\mathrm{i}$ & j & 1 & \\
\hline $\mathrm{C}_{1}$ & $43.88^{\star \star}$ & $0.62^{\star}$ & $-14.14^{\star}$ & -2.56 & $3.72^{*}$ & $12.76^{\star \star}$ & $\begin{array}{l}\text { Duplicate epistasis between } \\
\text { dominant decreasers }\end{array}$ \\
\hline $\mathrm{C}_{2}$ & $39.09 * *$ & $0.87^{* *}$ & 2.79 & 1.98 & -0.52 & -2.34 & \\
\hline $\mathrm{C}_{3}$ & $37.19 * \star$ & $2.67^{\star \star}$ & -2.41 & 2.08 & $-6.62^{\star \star}$ & 3.26 & \\
\hline $\mathrm{C}_{4}$ & $44.82^{\star \star}$ & $3.08 * \star$ & $-11.52^{* *}$ & $-5.96 * \star$ & $-4.36^{\star \star}$ & $6.08 *$ & $\begin{array}{l}\text { Duplicate epistasis between } \\
\text { dominant decreasers }\end{array}$ \\
\hline $\mathrm{C}_{5}$ & $38.17^{\star \star}$ & 0.25 & $9.29 *$ & 2.28 & -0.62 & $-8.86^{\star \star}$ & $\begin{array}{l}\text { Duplicate epistasis between } \\
\text { dominant increasers }\end{array}$ \\
\hline $\mathrm{C}_{6}$ & 48.20 ** & $2.05^{\star \star}$ & $-20.39 * \star$ & $-9.55^{\star \star}$ & $-7.35^{\star \star}$ & $10.39 * *$ & $\begin{array}{l}\text { Duplicate epistasis between } \\
\text { dominant decreasers }\end{array}$ \\
\hline $\mathrm{C}_{7}$ & $48.96 * \star$ & $2.46^{\star *}$ & $-20.68^{\star *}$ & $-10.72^{\star \star}$ & 2.76 & $14.72^{\star \star}$ & $\begin{array}{l}\text { Duplicate epistasis between } \\
\text { dominant decreasers }\end{array}$ \\
\hline $\mathrm{C}_{8}$ & $41.40^{\star \star}$ & 1.80 ** & 1.60 & $-3.00 *$ & 1.40 & -3.60 & \\
\hline $\mathrm{C}_{9}$ & $39.90 * *$ & $2.21^{\star *}$ & 0.29 & -2.00 & -0.02 & -0.54 & \\
\hline $\mathrm{C}_{10}$ & $44.59 * \star$ & 0.41 & $-15.37^{\star}$ & $-8.40^{\star \star}$ & -1.22 & 5.18 & $\begin{array}{l}\text { Duplicate epistasis between } \\
\text { dominant decreasers }\end{array}$ \\
\hline
\end{tabular}


In the second year of study, highly significant effects of additive genes were exhibited in crosses $\mathrm{C}_{2}, \mathrm{C}_{3}, \mathrm{C}_{4}, \mathrm{C}_{6}, \mathrm{C}_{7}, \mathrm{C}_{8}$ i $\mathrm{C}_{9}$, and a significant effect only in the cross $\mathrm{C}_{1}$. Highly significant effects of dominant genes were also found in crosses $\mathrm{C}_{4}$, $\mathrm{C}_{6}$ and $\mathrm{C}_{7}$, and significant effects of dominant genes in crosses $\mathrm{C}_{1}, \mathrm{C}_{5}$ and $\mathrm{C}_{10}$. In crosses $\mathrm{C}_{4}$ and $\mathrm{C}_{6}$, all three interactions $(i, j, l)$ were major contributors to epistasis. In the cross $\mathrm{C}_{1}$, major contributors were interactions $j$ and $l$, in the cross $\mathrm{C}_{5^{-}}$ interaction $l$, in the cross $\mathrm{C}_{10}$ - interaction $i$, and in the cross $\mathrm{C}_{7}$ - interactions $i$ and $l$.

In the first year of study, epistasis could not be classified in six crosses $\left(\mathrm{C}_{1}, \mathrm{C}_{3}\right.$, $\mathrm{C}_{4}, \mathrm{C}_{7}, \mathrm{C}_{8}$ and $\left.\mathrm{C}_{10}\right)$, and in the second year in four crosses $\left(\mathrm{C}_{2}, \mathrm{C}_{3}, \mathrm{C}_{8}\right.$ and $\left.\mathrm{C}_{9}\right)$ because neither dominant $(h)$ nor epistatic gene effects $(l)$ showed significance.

In the first year of study, duplicate epistasis between dominant increasers was exhibited in crosses $\mathrm{C}_{1}$ and $\mathrm{C}_{9}$ and duplicate epistasis between dominant decreasers in crosses $\mathrm{C}_{5}$ and $\mathrm{C}_{6}$. In the second year of study, dominant epistasis between dominant increasers was exhibited in only one cross $\left(C_{5}\right)$, while duplicate epistasis between dominant decreasers occurred in the remaining crosses $\left(\mathrm{C}_{1}, \mathrm{C}_{4}, \mathrm{C}_{6}, \mathrm{C}_{7}\right.$ and $\left.\mathrm{C}_{10}\right)$.

\section{REFERENCES}

Marinković, R., Škorić, D., 1984, 1985. Nasleđivanje mase 1000 semena i hektolitarske mase kod suncokreta $\mathrm{u} \mathrm{F}_{1}$ generaciji i komponente genetske varijabilnosti (Inheritance of 1000seed i hectoliter mass in $\mathrm{F}_{1}$ sunflowers and components of genetikc variability). Zbornik radova Instituta za ratarstvo i povrtarstvo-Novi Sad, 14-15, 62-71.

Mather K., 1949. Biometrical Genetics. Dover Publications, New York, USA

Mather K., and Jinks J. L., 1982. Biometrical Genetics. London, New York, Chapman and Hall.

Powers, L. 1941: Inheritance of quantitative characters in crosses involving two species of Lycopersicum. J. Agr. Res., 63: 149-174.

Soldatov K. I. i Mamonov I. F., 1972. Izučenie nasleduemosti naturi semjan podsolnečnika priznih sposobah razmnoženija (Study of inheritance...). Bjulten. naučnoj tehničeskoj informaciji po masljičnim kulturom VNIIMK. III., 3-8.

\section{INFLUENCIA DE GENES EN LA MASA HECTOLÍTRICA DE GIRASOL (Helianthus annuus $\mathrm{L}$.)}

RESUMEN

La influencia de los genes aditivos y dominantes y sus interacciones en la herencia del peso hectolítrico en 10 híbridos de girasol, creados por el cruzamiento de cinco líneas consanguíneas y deducidos de los sintéticos NS-S-1, fue investigada durante los años 2001 y 2002. La vinculación entre los valores medios esperados de la descendencia, fue investigada por una prueba de proporcionalidad (Mather, 1949), mientras que las evaluaciones de la influencia de genes y del modo de herencia, realizadas sobre la base del análisis de los valores medios de las generaciones (Mather and Jinks, 1982). El modelo aditivo dominante no era suficiente para explicar todos los cruzamientos de dos años de investigación. En los híbridos en los cuales el modelo no era suficiente, la influencia epistática de genes controlaba la herencia de las características investigadas. 
En el primer año de investigación, la doble epistasis entre los 'aumentadores' dominantes (dominant increasers) fue expresada en los cruzamientos $\mathrm{C}_{2} \mathrm{y} \mathrm{C}_{9}$, mientras que la doble epistasis entre los 'disminuidores' dominantes (dominant decreasers) se presentó en los cruzamientos $\mathrm{C}_{5} \mathrm{y}_{6}$. En el segundo año, la doble epistasis entre los 'aumentadores' dominantes fue expresada sólo en el cruzamiento $\mathrm{C}_{5}$, mientras que la doble epistasis entre los 'disminuidores' dominantes, se presentó en los cruzamientos $\mathrm{C}_{1}, \mathrm{C}_{4}, \mathrm{C}_{6}, \mathrm{C}_{7} \mathrm{y} \mathrm{C}_{10}$. En los cruzamientos $\mathrm{C}_{1}, \mathrm{C}_{3}, \mathrm{C}_{4}, \mathrm{C}_{7}, \mathrm{C}_{8} \mathrm{y} \mathrm{C}_{10}$ del primer año y los cruzamientos $\mathrm{C}_{2}, \mathrm{C}_{3}$, $\mathrm{C}_{8} \mathrm{y}$ del segundo año, no era posible determinar el tipo de epistasis, debido a que los valores de las componentes independientes (dominante y dominante $\times$ dominante) eran insignificativas.

\title{
ACTION DES GÈNES SUR LA MASSE D'HECTOLITRE CHEZ LE TOURNESOL (Helianthus annuus L.)
}

\author{
RÉSUMÉ
}

L'action des gènes additifs et dominants et leur interaction sur l'hérédité du poids de l'hectolitre chez 10 hybrides de tournesol développés par le croisement de cinq lignées autogames dérivées du synthétique NS-S-1 ont été analysées en 2001 et 2002. La liaison entre les valeurs moyennes des descendants a été contrôlée par la méthode des tests de graduation (Mather, 1949) tandis que l'estimation de l'action des gènes et du mode d'hérédité a été faite par l'analyse moyenne de génération (Mather et Jinks, 1982). Le modèle additif dominant n'était pas adéquat pour tous les croisements des deux années. Chez les hybrides pour lesquels le modèle n'était pas adéquat, l'action épistatique du gène était importante dans l'hérédité des caractères étudiés.

$\mathrm{Au}$ cours de la première année de l'étude, l'épistasie double entre les « augmentateurs » dominants (dominant increasers) s'est manifestée dans les croisements $\mathrm{C}_{2}$ et $\mathrm{C}_{9}$ tandis qu'une épistasie double entre les réducteurs dominants est apparue dans les croisements $\mathrm{C}_{5}$ et $\mathrm{C}_{6}$. Au cours de la deuxième année, une épistasie double entre les augmentateurs dominants ne s'est manifestée que dans le croisement $\mathrm{C}_{5}$ tandis qu'une épistasie double entre les réducteurs dominants est apparue dans les croisements $\mathrm{C}_{1}, \mathrm{C}_{4}, \mathrm{C}_{6}, \mathrm{C}_{7}$ et $\mathrm{C}_{10}$. Le type d'épistasie dans les croisements $\mathrm{C}_{1}, \mathrm{C}_{3}, \mathrm{C}_{4}, \mathrm{C}_{7}, \mathrm{C}_{8}$ et $\mathrm{C}_{10}$ n'a pas pu être déterminé au cours de la première année non plus que dans les croisements $\mathrm{C}_{2}, \mathrm{C}_{3}, \mathrm{C}_{8}$ et $\mathrm{C}_{9}$ au cours de la deuxième année parce que les valeurs des composantes non fixables (dominant et dominant $\mathrm{x}$ dominant) n'étaient pas significatives. 